Article

\title{
Vernacular Politics, Sectarianism, and National Identity among Syrian Refugees in Jordan
}

\author{
Sarah A. Tobin
}

Chr. Michelsen Institute, P.O. Box 6033 N-5892 Bergen, Norway; sarah.tobin@cmi.no; Tel.: +47-480-084-25

Received: 5 June 2018; Accepted: 11 July 2018; Published: 23 July 2018

\begin{abstract}
In Jordan-home to some one million Syrian refugees-the vital roles played by vernacular politics, discourses of inclusion and exclusion, and sectarian social histories for Syrians are often considered unimportant when examining possibilities for integration or coexistence. Based on ethnographic research and participation in women's religion classes in a Syrian refugee camp in Jordan in 2014, I argue that while sectarian identities may not in and of themselves appear to divide the majority of Syrian refugees in Jordan from the majority of Jordanian residents (as Sunni Muslims), through utilizing a vernacular politics theoretical perspective I reveal that the sectarian orientations and localized histories of Syrian refugees have an understudied potential to create new forms of divisiveness in Jordanian society. To dismiss any concerns raised, Jordanians reinforce the idea that sectarian discourses, in an objectified sense, are not welcome in Jordan, and that they are even-as a few asserted-“against Islam". These differing national experiences with vernacular politics expressed in sectarian terms prompt Jordanians to reinforce the narrative that Jordan is free of such divisions, and will continue to remain so. This paper concludes by discussing the implications for national-transnational tensions.
\end{abstract}

Keywords: Islamic sectarianism; Syrian refugees; vernacular politics; integration; interdisciplinarity

\section{Introduction}

The Syrian refugee crisis has hit Jordan hard (Sullivan and Tobin 2014). The United Nations High Commissioner for Refugees (UNHCR) indicates that as early as September 2014, there were over 600,000 registered "persons of concern" in Jordan. The Jordanian government has held the number at one million or more, believing that some 400,000 "unregistered refugees" have not sought the formalization of their status as refugees with the UNHCR. Most of these refugees in Jordan are from the nearby southern Syrian region of Dara'a, where the uprising began in 2011.

The Jordanian government and populace share many concerns about this large influx and settlement of foreigners. These refugees are believed to be a comprehensive and robust drain on economic resources (The Impact of Syrian Refugees on Jordan's Economy 2016), as well as noticeable and tangible users of precious natural resources (Farishta 2014), and are increasingly seen as a security threat (Carefully Watched 2014). This is also occurring in other Middle East host countries where Syrian refugees are additionally viewed as a demographic threat, which is particularly due to concerns about heightened and politically-charged sectarianism. These issues have a history of dividing Muslim communities, especially in such host-country contexts, and thus retain the potential to do so again.

Sectarianism, or ta'ifiyya, was, even in its origins, deemed a divisive threat to the Muslim community, and is warned against in the Qur'an (30: 31-33):

"... do not be of those who associate others with Allah, or of those who have divided their religion and become sects, every faction rejoicing in what it has. And when adversity touches the people, they call upon their Lord, turning in repentance to Him. Then when He lets them taste mercy from Him, at once a party of them associates with their Lord". 
Despite the warnings, as early as $656 \mathrm{CE}$, questions about proper Islamic authority and social relations between those on differing sides of political divides emerged, particularly among those involved in the emergent Sunni/Shi'a divisions ${ }^{1}$. While there have been some substantial periods of peaceful coexistence and harmony between Sunnis and Shi'as in Islamic and political history, it is generally believed that the Iranian revolution of 1979 most recently fomented political violence and social discord in contemporary Muslim countries, especially among the Sunni-majority Arab states of the Middle East (Esposito 2003a). The effects of the rise of sectarianism in the Middle East had tremendous political and socio-cultural effects throughout the region, including fomenting internal national differences (at times violently) as in the case of Iraq, establishing durable ruling regimes as in the cases of Lebanon and Syria, and entrenching Sunni allegiance and adherence as in the case of Jordan (there is voluminous literature on this. See, for example, Gause 2014; Nasr 2004, 2006; and Sivan 1989). Furthermore, increasing sectarian tensions are often attributed to being a cause of the Syrian civil war (see, for example, Gause 2014 and Ryan 2012). These concerns become particularly pressing today with the large influx of Syrian refugees around the Middle East and beyond.

Lebanon, for example, has a long and visible history with sectarianism, where confessional politics determine that the President is Maronite Christian, the Speaker of the Parliament is Shi'a, and the Prime Minister is Sunni. This delicate articulation of political power-sharing is based on a long-standing demographic estimate of $40 \%$ Christian, 27\% Shi'a, and 27\% Sunni. Sectarianism in this national context is the means by which the nation-state is politically constructed, negotiated, and a unity-in-diversity has prompted a tenuous and fragile peace for those who clearly remember their own devastating civil war. Sectarianism in Lebanon is "a neologism born in the age of nationalism to signify the antithesis of nation; its meaning is predicated on and constructed against a territorially bounded liberal nation-state" (Makdisi 1996). Much of the contemporary concerns about sectarianism focus on how the influx of Sunni Syrians may throw off the tenuous balance of sectarian power and peace. Syrian refugees, some analysts assert, threaten to undermine this (Meier 2014).

In the case of Turkey, the Turkish reception of Syrians has reportedly been quite accusatory of sectarian biases. Syrians interpret this as an attempt to pull them into Turkish sectarian politics, particularly in an overt attempt to shore up the government's support for the Sunnis (Özden 2013). Furthermore, some Syrians reported that sectarian perspectives play out in terms of aid provisions: Turkmen families are perceived to receive higher levels of aid (Özden 2013, p. 6).

Accounts of Syrian refugees in Germany also articulate emergent tensions and social formationsas well as frustrations-based around durable sectarian identities from Syria, not only from the host country, but also from other refugees (see, for example, Eghdamian 2018). As (Eghdamian 2018) quotes a Syrian refugee in Berlin, before the Syrian crisis, "no one would care if you were a Muslim, Christian, Druze, or anything else. I am Syrian. We are all Syrian. But now, people want to know what your religion is, and then they will act differently towards you. This is the problem". As an Israeli journalist points out, identities among the displaced Syrians in Germany are less nationalist and more sectarian (Heilman 2018), which has important implications for the German reception of Syrians. This keen interest on the part of hosting countries-even if they are not overwhelmingly demographically different-plays out in important ways in Jordan.

Similar to the case of Lebanon, most of the Syrian refugees in Jordan are Sunni Muslims. However, unlike Lebanon, this coincides with the overwhelming demographic majority in Jordan, which is over $90 \%$ Sunni Muslim. Also dissimilar from the case of Lebanon is a national history that is defined not by religious sectarianism, but rather by waves of refugees and the durable ethnic divisiveness of

1 The two major divisions or denominations in Islam are between Sunnis and Shi'as. In $632 \mathrm{CE}$ and following the death of the Prophet Mohammed, a major dispute emerged between those who pledged allegiance to the religious and political leadership of either 'Ali ibn Abi Talib or Abu Bakr. The former became known as Shi'as, and the latter became known as Sunnis. The early divisions culminated in the Battle of Karbala, in which Yazid I killed Hussein ibn 'Ali. In contemporary times, it is estimated that between $85-90 \%$ of the world's Muslims are Sunnis, and $10-15 \%$ are Shi'as. 
Palestinians and Jordanians (Tobin 2016). As a result, many analysts and researchers have overlooked the possibilities for Syrian refugees to hold sectarian outlooks and perspectives that inform their interactions with Jordanians into the future. This article examines the following questions. What is sectarianism for Syrians? What are its impacts in a case that, at least at first glance, is not widely divergent from the host country, as there are primarily Sunni refugees with Sunni majority hosts?

Despite the increasing sectarian nature of both the Syrian war and the socio-cultural practices of Syrians in conditions of displacement, there is a relative dearth of studies that examine interreligious dynamics as part of the refugee-hosting and host-country experiences and impacts (Eghdamian 2015, 2017). Thus, based on an interest in bringing anthropological and cultural perspectives to bear on such discussions, I participated in and conducted ethnographic research in two women's religion classes in a Syrian refugee camp in Jordan. I also interviewed Syrian refugees about the courses' content and obtained Jordanian reflections of the religion classes and interviews with the Syrian refugees during the summer of 2014. With this, I discuss the key issues at stake for Syrian refugees in Jordan with regard to their sectarian experiences in Syria and preliminary reactions of some Jordanians.

I argue that while sectarian identities may not in and of themselves appear to divide the majority of Syrian refugees in Jordan from the majority of Jordanian residents (as Sunni Muslims), utilizing a vernacular politics theoretical perspective reveals that the sectarian orientations and localized histories of Syrian refugees have an understudied potential to create new forms of divisiveness in Jordanian society. To dismiss any concerns raised, Jordanians reinforce the idea that sectarian discourses, in an objectified sense, are not welcome in Jordan, and that they are even—as a few asserted-“against Islam". In conclusion, the article demonstrates that the influx of sectarian outlooks held by Syrian refugees prompt Jordanians to reinforce the nationalist narrative that Jordan is free of such divisions and will continue to remain so, as justified in religious terms, in order to remain "true" to Islam.

\section{Results}

\subsection{Islamic Sectarianism in the Literature}

Importantly, sectarianism in the contemporary Middle East has strong disciplinary roots. The study of sectarianism is often considered to be the purview of political scientists, specialists in international affairs, and political pundits with a wide lay audience. For some political commentators, sectarianism is considered a fixed, even-in at least some instances-biological category, which can be activated by poor political structures and contexts of uncertainty, instability, and violence ${ }^{2}$. For other political commentators, sectarian identities are often discussed as substitutes for structures of governance, extensions of kinship or family structures, or another type of ethnic identity. Additionally, some argue that the presence of sectarian preferences can signal problematics, tensions, irrationality, and-perhaps most importantly-a durable religious/ethnic national identity that challenges our own civic national identity. There are three theoretical approaches that are dominant in the literature on sectarianism, each of which proves insufficient in understanding the Syrian, and especially Syrian diaspora case: primordialist, instrumentalist, and institutionalist. I discuss each of them in turn.

Some understandings of sectarianism turn towards primordialism (Malmvig 2015). This approach assumes that sectarianism is fundamental to a person's identity. This has been relatively unchanged over time and is beyond the lifetime of an individual; it is a long-sustained category that is often understood as "ancient" and is still somehow inescapable, perhaps even biological in its roots. The claims in this discursive space include, for example: Sunnis and Shi'a's have never gotten along; they have always been and will be in conflict. The only explanation that is deemed necessary in this

2 This is, of course, a very controversial understanding of sectarianism that derives from largely now-discredited notions about biological racism. The "Clash of Civilizations" thesis, for example, may interpreted as promoting a biological and, therefore, inevitable perspective on the future of political conflict that is based on religious and sectarian differences (see, for example, O’Hagan 2000). Despite the discredited status, the argument continues to have some currency. 
approach is one of long-passed historical precedence, with dualist and predetermined outcomes that ignore identities and experiences that are more complex. Furthermore, in this framework, sectarian identities are latent divisions awaiting activation, or worse, in need of suppression (Abdo 2013; Lynch 2013). This approach has wide currency in the media and policy analysis (see, for example, Sherwood 2016 and Hall 2016; for a refutation of this position, see also Fisher 2016).

Another approach is instrumentalism, which holds that sectarianism is a function of power-seeking elites and political entrepreneurs that appeal to sectarian ideas for their own ends. Sectarianism is understood as a "superficial political construct" (Malmvig 2015). This approach typically places the explanatory force on that of authoritarian regimes who "use sectarian fear-mongering to garner vested patron-client relationships, as gateways to mass mobilization, or as powerful levers in regional rivalries" (Malmvig 2015). The explanatory power in this approach comes from the authoritarian regimes and their modes of operation. This approach emphasizes that sectarian ideas are recognized as complex and overlapping, and are also able to be appealed to, manipulated, and utilized for a regime's own political and economic gain.

Finally, institutionalization takes instrumentalism a step further: states become complicit in furthering sectarian identity politics (however they may land) by institutionalizing a particular sectarian position through the bureaucratic administrators, authorities, arms, and entities of the state, and through the actions of citizens. As Weiss argues, during the French Mandate of Lebanon claims of the "right to difference" amongst the Shi'a and the institutionalization of Shi'i law and society "led to an increased visibility of the Shi'i community and the reinforcement of claims of sectarian difference, as well as a subtle shift towards greater Shi'i participation in public life" (Weiss 2010, p. 155). This approach also assumes that sectarianism is latent, static, and also threatening and in need of control. Sectarian identities in this approach are subject to overt manipulations, in-group/out-group political violence, and mobilization through legal and administrative apparatuses of the state. This is the perspective behind the idea that Iran is the greatest threat in a regional "sphere of influence" and the menacing ideology of the Shi'a crescent, as discussed below.

Perhaps more immediately, sectarianism also challenges current state-building efforts and state-society relations in the Middle East. States that had been understood as particularly strong, nationalist, and secular, such as Iraq and Syria, seemingly fractured along ethnic and sectarian lines. While many in the Western media are keen to say that this has little to nothing to do with sectarianism (see, for example, Shakman Hurd 2013) and everything to do with authoritarianism, political economy, and foreign relations, in fact, this raises a set of vexing questions about sectarianism that anthropological theories of sectarianism are uniquely poised to answer: How do/did Syrians perceive, experience, and reconfigure religious-based differences, especially in conditions of authoritarianism, conflict, violence, and instability? Furthermore, why sectarianism, and why now?

\section{2. "Poetics of Accusation" and Vernacular Politics: Anthropological Theories of Islamic Sectarianism}

Sectarian affiliations for Syrians have fused with class and regional experiences in idioms that express dissatisfactions and disappointments through group affiliations, as these groups are "believed to determine access to positions of power and influence" (Salamandra 2013, 2014). These agonistic discourses are what Salamandra (2004), in her important ethnographic research among Syrians, refers to as the "poetics of accusation". Such discourses serve as a mode of sociability wherein disappointment, frustration, and alienation against—in this case- the Syrian nationalist project come to the fore, and do so particularly in group formation, because group affiliations are believed to determine access to positions of power and influence. Sectarianism encompasses a potent mix of class, regional, and religious distinctions, all of which were newly engendered and enhanced by the Ba'athist regime. Rather than a primordial or racial category (or even arguably a religious category), this social scientific theory of sectarianism pushes forth the notion that sectarianism is very much a social and cultural category constructed by specific political and economic moments in the 20th century in particular, and constituted by vernacular politics. As a result, sectarianism is an important lens for understanding 
20th century political, economic, and social (re)formations in Syria. Sectarianism in Syria worked as a social and cultural technology (Mikdashi 2011) that organizes contemporary relationships based on historical narratives, and it is wielded often by elites to protect self-interests and acts as a "shortcut" to effective ruling.

In the last four decades, a veneer of socialist secularism has helped raise Al-Assad's kleptocracy (Salamandra 2013). Syria's Shi'i-'Alawi community constituted approximately 10-15\% of the total pre-war population, and they experienced a profound reversal of fortunes in living memory. When the Ba'ath party came to power in 1963, political power shifted from the majority-Sunni Muslim elites-to a largely rural military elite dominated by the 'Alawis. Elite Sunnis were displaced from high-ranking positions in Damascus and Aleppo, and they were forced to conduct business with those 'Alawis who only a few years earlier served as household workers from coastal areas. "A cold peace ensued, anchored by shared interest, but laced with mutual resentment" (Salamandra 2013, p. 305). 'Alawis resent Damascenes, or the Sunni merchant elites, and Damascenes resent the 'Alawi control of licensing and smuggling. Those excluded from both of these groups-a majority of the country, including many Christians and secularists, those from many other sectarian minorities, and many poorer and rural Sunnis-resented them both. Vernacular politics has rendered the 'Alawis synonymous with connections to power military and foreign relations, and the Sunni elites with profiteering and reinforcing the status quo. Sectarian discourses of resentment have become salient social and cultural formations that have fueled the civil war. A strong state should not be confused with a sentiment of nationhood.

Jordan, by contrast, has maintained a very strong anti-sectarian perspective, primarily due to its homogeneity as a Sunni-dominant country. Socio-culturally, it is much more religiously homogenous than most of its neighbors, and is self-described by many, including the King himself, as "non-sectarian" (Tarifi and Alawsat 2013). When discussing the vulnerabilities of Jordan to sectarian divisions, King 'Abdullah II said, "we are the least vulnerable to the risk of sectarian divisions and tensions due to the homogeneous makeup of Jordanian society—thank God for that-and the historical process of building a collective national identity. These elements have guaranteed that we never slipped into sectarian or ethnic conflicts throughout our history" (Tarifi and Alawsat 2013).

Simultaneously and contradictorily, the Hashemite monarchy has been an outspoken critic of the rise of Shi'a political power in the region, which was believed to see the rise of Iran and proxy Shi'a leadership as a direct threat. In fact, it was King 'Abdullah who coined the now well-known term "the Shi'a Crescent" in 2004. The term gained much traction later when, while on Hardball with Chris Matthews in December of 2008, the King said, "If it was a Shi'a-led Iraq that had a special relationship with Iran, and you look at that relationship with Syria and with Hezbollah-Lebanon, then we have this new crescent that appears that would be very destabilizing for the Gulf countries and actually for the whole region" (MSNBC 2004). At the time, the term was originally used in 2004; Iran was reportedly interfering in Iraq in the run-up to the January 2005 parliamentary elections. This was in the context of a threatened, and later realized, boycott of the elections by Sunnis in Iraq, potentially leading to a Shi'a-dominated government and the assumption that a Shi'a Iraq might fall under the influence of Shi'a Iran. The suggestion in the term, which was later picked up in the United States (U.S.) media and is now quite commonplace in social scientific and popular discussions of the region, was that the common religion of Shi'i Islam underscores strong potential for cooperation between Iran, Iraq, 'Alawite-dominated Syria, and the politically powerful Shi'a-militia Hezbollah in Lebanon; as well, the suggestion was that these others would be proxies for Iran in a regional power play. The quotation and term has since occupied much attention and served as a rhetorical hook for larger generalizations and characterizations of the so called "Sunni-Shi'a divide" across the Levant-from Beirut and Damascus to Tehran and through Baghdad—and down to the Persian Gulf. In reality, the crescent geographically gives a false sense of an encompassing geography of inevitable Shi'a-dominance and a political belt cementing chaos and instability as Sunni leaders are disenfranchised and the Sunni populace is marginalized. 
These are contradictory messages: Jordan is both free of internal sectarian divisions and also subject to (if not promoting overtly its perceived position as vulnerable to) sectarian geopolitical events. This contradictory positioning is not lost on the populace. In vernacular politics, the contradiction means that there is widespread fear that Syrians bring sectarian divisions, and potential latent hostilities and violence. The fear in Jordan is that the vernacular will meet regional politics in disruptive ways by the Syrians, who ascribe to and believe in sectarian forms of identity and social organization. There is widespread fear about disruption in the nation that aspires to a status as a nation of "stability and security" (Tobin 2012). With Jordan having taken in—by some estimates—as many as one million+ refugees, the concerns are both politically and socially relevant.

\section{3. "Dars Deen" in Cyber City}

Cyber City is part of a complex of Qualified Industrial Zone (QIZ) buildings that were rented out by the Jordanian government to host the growing number of refugees (Alahmed 2015). The building consists of six stories, two units, and two communal kitchens per floor, and 12 rooms in each unit. The building has the capacity to hold around 480 people. Surrounding the building, there are about 14 non-governmental organizations (NGOs), such as UNHCR and Save the Children, who provide basic needs and services to the refugees. In addition, the small area also contains a mosque, two supermarkets, a playground, and an activity center. The entire camp is under the management of the Jordanian Ministry of Interior.

As of June 2014, at the time of the research, the number of refugees in Cyber City reached 397, which was around 90 families, who consisted of either completely Palestinian members, or Syrians mixed with Palestinian families; $50 \%$ of the people themselves were Palestinians. Residents of Cyber City came from the Yarmouk and Dara'a Palestinian refugee camps, the Dara'a region, and elsewhere. Two sisters were from Homs, and had arrived in Jordan via a lengthy trip across the eastern desert. Life in Cyber City was deemed to be a tough one, as rules and regulations for those in the camp were becoming stricter and more constrained. Palestinians and their families were not allowed to attain any formal identification card or a Ministry of Interior card (MOI card), which would define their status as refugees and render the benefits due to them. They are extremely isolated.

Umm Mohammed is a Jordanian woman from the nearby town of Ramtha. She has a degree in Islamic Sciences from a local, public university (as all religious teaching falls under the Ministry of Islamic Endowments, or Awqaaf). Umm Mohammed comes to Cyber City every day to work with the women, particularly by offering a daily religion class or dars deen. I attended the dars on several occasions, and the women were always warm and welcoming toward me. The topics ranged from Islamic ideas of women to the character of the Prophet Mohammed. Each class was taught at a middle-school level, which is not dissimilar to the levels of a typical Sunday sermon in the U.S. or a Friday khutba in Jordan, and classes were typically offered every other day.

This was the only religious lesson of its kind in Cyber City. This was a small refugee camp that was highly securitized and tightly controlled, and a plethora of religious leaders and classes would not have been tolerated by the Jordanian government. As I was conducting research in Cyber City on a near daily basis during that time, my attending the dars deen from Umm Mohammed was seen by the Syrians as a more social time. The women passed around sweets and drank tea, for example. I also spoke more informally with the women before and after the dars. I enjoyed playing with their children at this time as well.

I attended one of Umm Mohammed's religion lessons in mid-June 2014 that had approximately 30 women in attendance. It focused on the topic of shirk, or polytheism, which is considered an unpardonable sin and one that guarantees hellfire. Over the course of the hour, Umm Mohammed had a captive audience of women engaged in these questions of the large shirk, which worships something equal to God as in polytheism by the mishrikeen, and the smaller shirk, which is a means of elevating oneself closer to God. 
In this dars, Umm Mohammed systematically draws Muslim in-group and non-Muslim out-group placements, engaging in what is called takfir, or declaring someone or some group of people to be unbelievers and outside of Islam (loosely, excommunicated). ${ }^{3}$ Umm Mohammed said:

“One can accidently fall into Shirk Akbar without realizing it. When you pray 'Oh, Prophet of Allah, release me from my problems!' you have asked the Prophet only that which is capable of Allah himself. Even though all of the prophets are the highest of all humanity, you cannot ask them for what is Allah's capability. They are humans who had their own problems and imperfections. The Sufis are examples of people who resort to asking other humans for help in their prayers ... Another example we talked about before in a longer lesson, the people who go to the graves (Alkuboryon). They would go to visit the graves of well-known people, idols, or prophets, and they would pray to them and ask them for help. This happens a lot in Syria to known individuals ${ }^{4}$. The Shi'as in the 10th of Muharram, they go to the maqam (tomb) of Hussain bin Ali in Karballa [Iraq] and pray and take the sand around it as they consider it the only clean thing to pray on. This is the greatest shirk... Surat Alekhlas (a chapter in the Qur'an) is a description of how there is no God but Allah. It also refers to fact that Allah has no partner, no father, and no son, like the Christians say, why? Because he doesn't need those like us humans do. We need the partner and the father and the son ... This is another example of Shirk Akbar. Again to reiterate, Shirk Akbar invalidates and negates Islam completely".

In this passage and in one fell swoop, Umm Mohammed declares that Sufis, pilgrims to saints' tombs (Alkuboryon), Shi'as, and Christians are negating Islam completely, and are therefore committing the unpardonable sin.

Umm Mohammed went on:

"The Ba'ath Party, one of the oldest parties to form in Syria, where Assad and his government came from. Assad said: the Ba'ath [party] is my God. They killed many young men previously because they refused to say that there is no God but Bashar. No God but Bashar al-Assad".

"I heard some people around here [Cyber City] saying that if Allah wanted to solve this situation [the Syrian Civil War and refugee crisis], He would have. This is kofar (blasphemy). Don't forget that there are many problems going around the world in so many countries ... First there was the Arab Spring. Then, there was the war in Afghanistan and the war in Iraq. These are wars against the Middle East. These are wars of the West against those who say the shahada (the proclamation of belief in Islam $)^{5}$. These are wars of fitna that turn brothers against brothers"' ${ }^{6}$

At this point, one of women, Um Sameer, interjected that that the Syrian Civil War is a war against Muslims and Islam, and that they [undefined and unclear pronoun] want to eradicate all Muslims.

These comments are telling for three reasons. First, they demonstrate the "poetics of accusation" (Salamandra 2004). This group of refugees, some of whom were twice-displaced as Palestinians from Syria, is particularly marginal. They came from a poor and largely ignored or even persecuted part of Syria. As Palestinians or Syrians in Palestinian families, the echoes of being forgotten by everyone

3 The act of takfir derives from a notable 20th-century Egyptian Islamist theorist, Sayyid Qutb, who wrote extensively on the maladies of the apostasy found in modern nation-states, and proposed "remedies" through an idealized Islamic faith. He advocated that takfir is incumbent on Muslims in contexts in which the state and its leaders are acting in corrupt ways. However, it is considered quite controversial, and mainstream and establishment Islamic scholars oppose the practice, asserting that it promotes zealotry, sanctions violence against the state and society, and is ultimately a forbidden act in Islam. See (Karawan 1995; Esposito 2003b).

4 Here, Umm Mohammed is referencing Sayyidah Zaynab bint 'Ali, who was one of the daughters of 'Ali, the fourth Islamic caliphate and the first Shi'a Imam, and Sayyidah Ruqayya, who is also known as Sukayna bint Husayn, was a young daughter of Al-Husayn ibn 'Ali and is commemorated in Shi'a tradition. Both of these notable Shi'a women are believed to be buried in Damascus in mosques named after each of them, respectively. These mosques are often sites for Shi'a pilgrimage.

5 The Islamic statement of faith, testimony, or "witness" translates to "There is no god, but God (Allah), and Mohammed is the Prophet of God (Allah)". Reciting the shahada is the first of the five pillars of Islam. The shahada is generally agreed to require a heartfelt faith and sincerity of belief, and its recitation is considered a "work of the tongue". See (Clarke 2009).

6 Fitna derives from the Arabic root $(f-t-n)$, which means "to burn". The word is literally a burning of temptation or trial. By extension, it also means sedition and civil strife. References in early Islam point to the trials and tribulations faced by the early Muslim community, particularly those that led to the division of the Muslim community into Sunnis and Shi'as. See (Williams 2009). This is also discussed in detail later in this article. 
cannot be understated. Who has reached out to save them in their historical experiences? Not the Shi'as, not the Christians, not the pious that visit saints tombs, and not the Sufis. Fellow religionists have long failed this population, as has the Ba'athist regime, and so has the West. Vernacular politics and the poetics of accusation here reveal long-standing complaints and frustrations about neglect, exclusion, violence, and histories of multiple displacements. A justification that the accused are all "against Islam" is a way to say that they are all against this group-against a group of practicing and sincere Muslims for whom there should be some semblance of sympathy and compassion. Religious terminology here is, arguably, a language for a political, economic, and social history of exclusion that has resulted in one of the most dire encamped scenarios of all Syrian refugees. ${ }^{7}$

In response to this dars, I conducted two focus groups. One group was composed of relatively more pious Muslim Jordanians and Palestinians, and the other was a mix of pious and non-pious Muslim Jordanians and Palestinians. All had traveled outside of Jordan; all of them spoke at least some English. All of the participants agreed with the statement "Jordan is not a sectarian society". They also agreed with the statement, "it is the responsibility of the majority religion to protect the minority religions". In response to the dars deen, the reaction was overwhelmingly that the dars promoted unfair and distorted stereotypes of each group, and that such characterizations were overly simplified and not at all nuanced. Some notable quotes from these focus groups included:

"Umm Mohammed should have her credentials revoked. This isn't learning. This is brainwashing".

"These women don't understand Christianity. The idea that Christians believe in three Gods is the stuff of myths and stereotypes. Anyone who has studied Christianity knows that's not true-it's one God with three faces".

"If this message was said over a loudspeaker on a Friday, there would be protests all over Amman. You can't say these things in Jordan. People don't believe it and won't respect it. We believe that your neighbors are your friends in Ahl Al-Kitaab [People of the Abrahamic Tradition], and Umm Mohammed is wrong. The Arab Spring was not a conspiracy of the West to create conflict between Muslims! In fact, for her to create this conflict between us and our neighbors is fitna".

Historically and by contrast, fitna was used to describe the large-scale militarily and politically-laden civil wars within Muslim societies, such as the killing of Uthman and the establishment of the Ummayyed Dynasty in the 650s and 660s, and the Battle of Karbala in 680. There are five major fitnas in Islamic history (those are two of them), and they are events that all occurred before the year 866, and tend to focus on the caliphates, holy and political succession, and dynastic leadership and rule. Fitna can also be used to describe an attractive but ultimately bad-for-you enticement to "temptation", "trial", or "test". 8

In the context of the Jordanian focus group, fitna is being used to refer to the creation of discord and problems between all the faithful of God, not only between Muslims. My focus group developed and invoked a very contemporary and unusual application of the term. However, there is no direct historical precedent or other contemporary application for referring to threats to pluralistic harmony between religious groups within the context of the nation-state as fitna. It is a reinvigorated usage of

7 It is important to note that some scholars of Jordan or the region might see the content of the dars as quite shocking. I did. I have never heard Jordanians talking like this. Occasionally there are anti-Semitic comments-typically tied to Israel and Zionists—and very rarely comments against Shi'as by Jordanians-most of whom have never met any Shi'as, or least none that they know of. However, I have never heard this kind of language in Jordan against Christians or "the West", or against people who pray at saints' tombs.

8 Fitna is also the title of a 2008 short film by Dutch parliamentarian Geert Wilders that was highly criticized and delegitimized. Approximately 17 minutes in length, the film attempts to demonstrate that the Qur'an motivates its followers to hate all who violate Islamic teachings. The movie shows selected excerpts from the Qur'an, interspersed with media clips and newspaper cuttings showing or describing acts of violence and/or hatred by Muslims. The film argues that Islam encourages-among other things—acts of terrorism, anti-semitism, violence against women, violence and subjugation of infidels and against homosexuals, and Islamic universalism. In an interview, Wilders stated that he specifically wanted a title that also features in the Quran. In his opinion, the word fitna refers to situations in which a Muslim's faith is tested. He claimed that he uses the term "reciprocally". Mr. Wilders said: "Islam and the Koran are my ordeal. For me, this pernicious Islam is fitna" (Trouw 2008). 
an Islamic in a new and contemporary application. In fact, that the earliest Qur'anic revelations use the word fitna to describe the persecution of early Muslims, especially by pre-Islamic polytheists (not Christians), renders this usage highly innovative and quite unusual.

\section{Discussion}

Concerns about religious difference in Jordan are running high: there is widespread fear of divisions within the populace, as well as documented and deeply disconcerting support for Islamic fundamentalism and ISIS (Schenker 2014) ${ }^{9}$. There are also political and socio-cultural actions aimed to protect Jordan's relative security, despite waves of potential destabilization from both within and from outside the country. With each wave, the Jordanian populace and government aim to emphasize similarity, cohesion, and a sense of togetherness, even if such differences are non-factual and contrived (Tobin 2016). The Jordan populace and government have no desire to be like its neighbors—any of them (Tobin 2012, 2016). This article demonstrates that the trend continues with Syrian refugees: the influx of sectarian outlooks held by Syrian refugees prompts Jordanians to "double down": to reinforce the narrative that Jordan is free of religious divisions and will continue to remain so, particularly in nationalist narratives and with unusual and distinctive theological underpinnings.

This assertion that Jordan is a contemporary home for peaceful pluralism in a neighborhood of dangerous sectarianism is complicated by the person of Umm Mohammed. Who is Umm Mohammed? She is a Jordanian who was trained in the Islamic sciences at a northern Jordanian, state-run university. As a result, and in theory, she should not be espousing such controversial ideas or promoting sectarian divisions, even (or especially) among encamped Syrian refugees. Yet, she did.

Was she a simply an effective orator who knew her audience? This strikes me as the most likely scenario. The next day after this class, I attended another dars from Umm Mohammed. Before the class, Umm Mohammed asked my research assistant if I was offended, and she then opened the class by apologizing to me for the previous day's course content. The dars the second day was entitled "Respect for Women: The Prophet Mohammed's Example and What Islam Really Says About How to Treat Women". This struck me as a means to try to appeal to what she believed was closer to my sensibilities as a Western researcher.

There is further evidence that this is the likely case. It is worth revisiting a quote from the course discussed above in which Umm Mohammed admonished the women in the class:

"I heard some people around here [Cyber City] saying that if Allah wanted to solve this situation [the Syrian Civil War and refugee crisis], He would have. This is kofar (blasphemy). Don't forget that there are many problems going on around the world in so many countries ... First there was the Arab Spring. Then, there was the war in Afghanistan and the war in Iraq. These are wars against the Middle East. These are wars of the West against those who say the shahada. These are wars of fitna that turn brothers against brothers".

In this otherwise highly divisive, sectarian-oriented dars, Umm Mohammed reveals a slight crack in the language: sectarianism, it seems, is not an inevitable and divisive category for identity and politics. She indicates that all Muslims who say that shahada-brothers and sisters in the religion, both Shi'as and Sunnis-are subject to the war of the West upon them. Thus, they ought to unite against the West, she seems to say, rather than divide along sectarian lines within themselves. In this admonition, Umm Mohammed reveals a perspective that sectarianism is also contextual, punctuated in importance, and flexible. This is despite her contradictory comments earlier in the lesson.

9 It is currently believed that Jordan has one of the highest numbers of foreign fighters working for ISIS in Syria and Iraq, at around 2000 people. Furthermore, cities such as Ma'an and Zarqa display open support for ISIS. As of late 2014, only $62 \%$ of Jordanians labeled ISIS a terrorist organization. However, the very public and highly visible immolation of Jordanian fighter pilot Moaz Al-Kasabeh by ISIS, followed by the public outrage and galvanization of nationalist sentiment, appears to have lessened support for ISIS. 
The other possibility that explains the strongly sectarian content in Umm Mohammed's lesson is that she was sincere in her statements; she really does believe that these groups of religious adherents do negate Islam and are deserving of the hellfire. This strikes me as the lesser likely option. However, it is still feasible. Jordan does have a long and important history of fighting against Islamic extremism, particularly among preachers (see, for example, Minzili 2007; Tal 1995; Yom and Sammour 2017; Wiktorowicz 1999, 2011).

In fact, in November 2014 (just after conducting this fieldwork), the Jordanian government laid down new and expanded laws for some 5000 Muslim clerics in the country (Booth and Luck 2014). The minister for Islamic Affairs, Hayel Dawood, indicated that the clerics are "the ground forces against the extremists". He then made himself clear: preach moderation or you're out: "Once you cross the red line, you will not be let back in". Specifically, Jordan is demanding that preachers refrain from any speech that discusses "sectarianism and support for jihad and extremist thought". Sectarianism and the likes of Umm Mohammed's class are rendered dangerous and extremist speech, equivalent to fomenting jihad, and a criminal act.

The government's approach to legislate, criminalize, and enforce certain speech acts, ethics, and behaviors among its employees should curb the efforts of the likes of Umm Mohammed from discussing theological issues that are sectarian explicitly or in implication and intention. However, within the context of the refugee camps and especially among women, such regulations are less likely to matter, revealing the hierarchical ways (in both a knowledge-production and political sense) and gendered ways in which religious knowledge is cultivated and transmitted. Despite the high levels of securitization of Cyber City (due to the political status of many of the refugees as Palestinians from Syria), frankly speaking, the general Jordanian public and the government will care less about a women's class in a rural refugee camp that holds little promise of wider public integration than they will about the governmental response to a khutba given at a public mosque over the loudspeakers in a prominent Christian neighborhood of Amman. Speech acts such as these in Cyber City are easily dismissed as politically and socially inconsequential, lacking political currency, and even mere gossip among women.

In this way, vernacular politics also provides a point of entrée into the contradictory ways that alternative visions for and experiences with "the political" can and do enter into everyday life, especially as they cut class divisions and enhance community-centered and value-centered politics. The social scientific framework of vernacular politics in sectarianism is a particularly promising window into understanding how local politics might not scale up into the hierarchies of power, but instead remain part of the relevant and timely reference points for the local political economy, even as governments may seek to exploit them. Under Syria's authoritarian regime, the vernacular was, in many ways, the only politics that one could have. Sectarianism became a shorthand for the distinct national histories of Syria, their regional experiences, and the ways that class cut new cleavages over and over in a short period of time.

Vernacular politics in Jordan, by contrast, is constituted by narratives of cohesion (despite their lack of historical fact), a strong sense of propriety in political discourse, and long-standing ambivalences between ethnicities, tribes, and social classes that render the kind of sectarian shorthand witnessed among these encamped Syrians difficult to capture in wider Jordan. At the same time, official Jordanian state discourse is internally focused on promoting the shared values of cohesion and unity, while external narratives are contradictorily rife with alarmist reports of Shi'a encroachment on Sunni political power.

Finally, this case adds to our understanding of sectarianism. Rather than a primordial, latent identity subject to simple government manipulations, the social scientific theory of vernacular politics of sectarianism demonstrates that sectarianism is about socio-cultural claims by actors in their everyday lives. The politics of inclusion and exclusion, which are the frameworks for understanding group violence or net resources, or expressing dissatisfaction with the state-or the state project-take on a sectarian tenor. It is not the case that sectarianism is a base identity that plays out in predetermined 
ways. Rather, a closer look at the history, context, and-especially—cultural practices around sectarianism will be particularly relevant for policy discussions and understandings of the Syrian refugee crisis and host country relations for a long time to come.

Funding: This research received no external funding.

Acknowledgments: Special thanks to Denis Sullivan and the Carnegie Corporation of New York-funded Boston Consortium for Arab Region Studies for support in the research process. Thanks to Maisam Alahmed for research and translation assistance.

Conflicts of Interest: The author declares no conflict of interest. The funders had no role in the design of the study; in the collection, analyses, or interpretation of data; in the writing of the manuscript, and in the decision to publish the results.

\section{References}

Abdo, Geneive. 2013. The New Sectarianism: The Arab Uprisings and the Rebirth of the Sunni-Shi'a Divide. Available online: https:/ /www.brookings.edu/research/the-new-sectarianism-the-arab-uprisings-and-therebirth-of-the-shia-sunni-divide/ (accessed on 19 July 2018).

Alahmed, Maisam. 2015. Status-Less in Cyber City. Middle East Research and Information Project, Summer 2015. Available online: https:/ /www.merip.org/mer/mer275/status-less-cyber-city (accessed on 19 July 2018).

Booth, William, and Taylor Luck. 2014. Jordan's 'ground Forces against Extremists': Imams. The Washington Post, November 9. Available online: http://www.washingtonpost.com/world/middle_east/to-counterrise-of-the-islamic-state-jordan-imposes-rules-on-muslim-clerics/2014/11/09/4d5fce22-5937-11e4-bd61346aee66ba29_story.html (accessed on 4 June 2018).

Carefully Watched. 2014. The Economist. June 18. Available online: https:/ /www.economist.com/pomegranate/ 2014/06/18/ carefully-watched (accessed on 4 June 2018).

Clarke, Lynda. 2009. Shahādah. In The Oxford Encyclopedia of the Islamic World. Oxford: Oxford Islamic Studies Online, Available online: http:/ / www.oxfordislamicstudies.com/article/opr/t236/e0725 (accessed on 2 July 2018).

Eghdamian, Kat. 2015. Religious Minority Experiences of Displacement: Initial Lessons Learnt From Syrian Christian and Syrian Druze Refugees in Jordan. Policy Brief. London: University College London Migration Research Unit.

Eghdamian, Khatereh. 2017. Religious Identity and Experiences of Displacement: An Examination into the Discursive Representations of Syrian Refugees and Their Effects on Religious Minorities Living in Jordan. Journal of Refugee Studies 30: 447-67. [CrossRef]

Eghdamian, Khatereh. 2018. How to Overcome Religious Prejudice among Refugees. The Conversation, July 4. Available online: https:/ / theconversation.com/how-to-overcome-religious-prejudice-among-refugees90344 (accessed on 5 July 2018).

Esposito, John L., ed. 2003a. Sectarianism. In The Oxford Dictionary of Islam. Oxford: Oxford Islamic Studies Online, Available online: http:/ / www.oxfordislamicstudies.com/article/opr/t125/e2129 (accessed on 3 July 2018).

Esposito, John L., ed. 2003b. Takfir. In The Oxford Dictionary of Islam. Oxford: Oxford Islamic Studies Online, Available online: http:/ / www.oxfordislamicstudies.com/article/opr/t125/e2319 (accessed on 2 July 2018).

Farishta, Aleena. 2014. The Impact of Syrian Refugees on Jordan's Water Resources and Water Management Planning. Master's Thesis, Columbia University, New York, NY, USA; pp. 1-36.

Fisher, Max. 2016. The Real Roots of Sunni-Shia Conflict: Beyond the Myth of Ancient Religious Hatreds. Vox, January 5. Available online: https://www.vox.com/2016/1/5/10718456/sunni-shia (accessed on 6 July 2018).

Gause, F. Gregory, III. 2014. Beyond sectarianism: The new Middle East cold war. Brookings Doha Center Analysis Paper 11: 1-27.

Hall, John. 2016. Sunni and Shia: Islam's 1400-year-old Divide Explained. The Independent, January 5. Available online: https:/ / www.independent.co.uk/news/world/middle-east/sunni-and-shia-islams-1400-year-olddivide-explained-a6796131.html (accessed on 6 July 2018).

Heilman, Uriel. 2018. What Syrian Refugees in Germany Think about Israel Might Surprise You. Haaretz.com, April 10. Available online: https:/ / www.haaretz.com/what-syrian-refugees-in-germany-think-about-israelmight-surprise-you-1.5407685 (accessed on 5 July 2018). 
Karawan, Ibrahim A. 1995. Takfīr. In The Oxford Encyclopedia of the Islamic World. Oxford: Oxford Islamic Studies Online, Available online: http:/ / www.oxfordislamicstudies.com/article/opr/t236/e0779 (accessed on 2 July 2018).

Lynch, Marc. 2013. The Entrepreneurs of Cynical Sectarianism. Available online: https://pomeps.org/wpcontent/uploads/2014/06/POMEPS_Studies4_Sectarianism.pdf (accessed on 19 July 2018).

Makdisi, Ussama. 1996. The Modernity of Sectarianism in Lebanon I Middle East Research and Information Project. Middle East Research and Information Project. MER200:26. Available online: https:/ / www.merip. $\mathrm{org} / \mathrm{mer} /$ mer200/modernity-sectarianism-lebanon (accessed on 4 June 2018).

Malmvig, Helle. 2015. Coming in from the Cold: How We May Take Sectarian Identity Politics Seriously in the Middle East without Playing to the Tunes of Regional Power Elites. Available online: https: / pomeps.org/2015/08/19/coming-in-from-the-cold-how-we-may-take-sectarian-identitypolitics-seriously-in-the-middle-east-without-playing-to-the-tunes-of-regional-power-elites / (accessed on 19 July 2018).

Meier, Daniel. 2014. Lebanon: The Refugee Issue and the Threat of a Sectarian Confrontation. Oriente Moderno 94: 382-401. [CrossRef]

Mikdashi, Maya. 2011. What Is Political Sectarianism? Jadaliyya_aدلية, March 25. Available online: http: / / www.jadaliyya.com/pages/index/1008/what-is-political-sectarianism (accessed on 4 June 2018).

Minzili, Yair. 2007. The Jordanian Regime Fights the War of Ideas. Current Trends in Islamist Ideology 5: 61.

MSNBC. 2004. Jordan's Abdullah Concerned Iraq May Tilt toward Tehran. NBCNews.com. December 9. Available online: http:/ / www.nbcnews.com/id/6679939/ns/world_news-mideast_n_africa/t/jordans-abdullahconcerned-iraq-may-tilt-toward-tehran/ (accessed on 5 June 2018).

Nasr, Vali. 2004. Regional implications of Shi'a revival in Iraq. The Washington Quarterly 27: 5-24. [CrossRef]

Nasr, Vali. 2006. When the Shiites rise. Foreign Affairs 85: 58-74. [CrossRef]

O’Hagan, Jacinta. 2000. A ‘Clash of Civilizations'? In Contending Images of World Politics. London: Palgrave, pp. 135-49.

Özden, Senay. 2013. Syrian Refugees in Turkey. Available online: http:/ /cadmus.eui.eu/bitstream/handle/1814/ 29455/MPC-RR-2013\%2005.pdf?sequence=1\&isAllowed=y (accessed on 5 June 2018).

Ryan, Curtis. 2012. The new Arab cold war and the struggle for Syria. Middle East Report 262: 28-31.

Salamandra, Christa. 2004. A New Old Damascus: Authenticity and Distinction in Urban Syria. Bloomington: Indiana University Press.

Salamandra, Christa. 2013. Sectarianism in Syria: Anthropological Reflections. Middle East Critique 22: $303-6$. [CrossRef]

Salamandra, Christa. 2014. Reflections on Not Writing about the Syrian Conflict. Jadaliyya_, February 5. Available online: http:/ / www.jadaliyya.com/pages/index/16290/reflections-on-not-writing-about-thesyrian-confli (accessed on 4 June 2018).

Schenker, David. 2014. There's a Worrisome Amount of Support in Jordan for the Islamic State. The New Republic, October 20. Available online: http:/ / www.newrepublic.com/article/119909/islamic-state-isis-supportjordan-worrying-poll (accessed on 4 June 2018).

Shakman Hurd, Elizabeth. 2013. Stop Trying to Make Syria's War into a Sectarian Conflict. The Atlantic, March 15. Available online: https://www.theatlantic.com/international/archive/2013/03/stop-trying-to-makesyrias-war-into-a-sectarian-conflict/274060/ (accessed on 5 June 2018).

Sherwood, Harriet. 2016. Sunni-Shia Sectarianism at Root of Much of Middle East Violence. The Guardian, January 4. Available online: https:/ /www.theguardian.com/world/2016/jan/04/sunni-shia-sectarianism-middleeast-islam (accessed on 6 July 2018).

Sivan, Emmanuel. 1989. Sunni radicalism in the Middle East and the Iranian Revolution. International Journal of Middle East Studies 21: 1-30. [CrossRef]

Sullivan, Denis, and Sarah A. Tobin. 2014. Security and Resilience among Syrian Refugees in Jordan. Middle East Research and Information Project, October 14. Available online: https:/ /www.merip.org/mero/mero101414 (accessed on 4 June 2018).

Tal, Lawrence. 1995. Dealing with radical Islam: The case of Jordan. Survival 37: 139-56. [CrossRef]

Tarifi, Adel, and Asharq Alawsat. 2013. Transcript: Jordan Least Vulnerable to Risk of Sectarian Divisions-King-By Adel Tarifi, Asharq Alawsat-Jordan Vista. JordanVista. June 27. Available online: http: / / vista.sahafi.jo/art.php?id=2c35fa2f1fd545a4b540d2653ea72c1da227a50b (accessed on 4 June 2018). 
The Impact of Syrian Refugees on Jordan's Economy. 2016. Oxford Business Group, March 22. Available online: http:/ / www.oxfordbusinessgroup.com/news/impact-syrian-refugees-jordan $\backslash \mathrm{T} 1 \backslash$ textquoterightseconomy (accessed on 4 June 2018).

Tobin, Sarah A. 2012. Jordan's Arab Spring: The Middle Class and Anti-Revolution. Middle East Policy 19: 96-109. [CrossRef]

Tobin, Sarah A. 2016. Everyday Piety: Islam and Economy in Jordan. Ithaca: Cornell University Press.

Trouw. 2008. Netherlands: Islamization Crept in a Long Time Ago. Islam in Europe, April 27. Available online: http:/ / islamineurope.blogspot.com/2008/04/netherlands-islamization-crept-in-long.html (accessed on 5 June 2018).

Weiss, Max. 2010. In the Shadow of Sectarianism. Cambridge: Harvard University Press.

Wiktorowicz, Quintan. 1999. State power and the regulation of Islam in Jordan. Journal of Church and State 41: 677-96. [CrossRef]

Wiktorowicz, Quintan. 2011. The Management of Islamic Activism: Salafis, the Muslim Brotherhood, and State Power in Jordan. Albany: SUNY Press.

Williams, John Alden. 2009. Fitnah. In The Oxford Encyclopedia of the Islamic World. Oxford: Oxford Islamic Studies Online, Available online: http:/ / www.oxfordislamicstudies.com/article/opr/t236/e0251 (accessed on 2 July 2018).

Yom, Sean, and Katrina Sammour. 2017. Counterterrorism and youth radicalization in Jordan: Social and political dimensions. CTC Sentinel 10: 25-30.

(C) 2018 by the author. Licensee MDPI, Basel, Switzerland. This article is an open access article distributed under the terms and conditions of the Creative Commons Attribution (CC BY) license (http:// creativecommons.org/licenses/by/4.0/). 